\title{
Production of Cold-Active Bacterial Lipases through Semisolid State Fermentation Using Oil Cakes
}

\author{
Babu Joseph, ${ }^{1,2}$ Supriya Upadhyaya, ${ }^{1,3}$ and Pramod Ramteke ${ }^{1,4}$ \\ ${ }^{1}$ Department of Microbiology and Microbial Technology, College of Biotechnology and Allied Sciences, \\ Allahabad Agricultural Institute-Deemed University, Uttar Pradesh, Allahabad-211007, India \\ ${ }^{2}$ College of Applied Medical Sciences, Shaqra University, Shaqra 11961, Saudi Arabia \\ ${ }^{3}$ Department of Microbiology, Institute of Medical Sciences, Banaras Hindu University, Varanasi 221 005, India \\ ${ }^{4}$ Department of Biological Sciences, School of Basic Sciences, Sam Higginbottom Institute of Agriculture, Technology and Sciences, \\ Uttar Pradesh, Allahabad 211 007, India
}

Correspondence should be addressed to Babu Joseph, babuaaidu@yahoo.co.in

Received 19 December 2010; Revised 20 February 2011; Accepted 23 February 2011

Academic Editor: Alane Beatriz Vermelho

Copyright () 2011 Babu Joseph et al. This is an open access article distributed under the Creative Commons Attribution License, which permits unrestricted use, distribution, and reproduction in any medium, provided the original work is properly cited.

\begin{abstract}
Production of cold active lipase by semisolid state fermentation involves the use of agroindustrial residues. In the present study, semisolid state fermentation was carried out for the production of cold active lipase using Micrococcus roseus, isolated from soil samples of Gangotri glaciers, Western Himalayas. Among various substrate tested, groundnut oil cake (GOC) favored maximal yield of lipases at $15 \pm 1{ }^{\circ} \mathrm{C}$ within $48 \mathrm{~h}$. Supplementation of glucose $1 \%(\mathrm{w} / \mathrm{v})$ as additional carbon source and ammonium nitrate $2 \%(\mathrm{w} / \mathrm{v})$ as additional nitrogen source enhanced production of lipase. Addition of triglycerides $0.5 \%(\mathrm{v} / \mathrm{v})$ tends to repress the lipase production. Further mixed preparation of groundnut oil cake (GOC) along with mustard oil cake (MOC) in the ratio of $1: 1$, and its optimization resulted in improved production of cold active lipase. The enzyme exhibited maximum activity at $10-$ $15^{\circ} \mathrm{C}$ and was stable at temperatures lower than $30^{\circ} \mathrm{C}$. The lipase exhibited optimum activity at $\mathrm{pH} 8$ and showed more than $60 \%$ stability at $\mathrm{pH} 9$. Semisolid state fermentation process by utilizing agroindustrial wastes will direct to large-scale commercialization of lipase catalyzed process in cost-effective systems.
\end{abstract}

\section{Introduction}

The Gangotri is the second largest Himalayan glacier, situated in the Uttarkashi of Uttaranchal (India) between $30^{\circ} 44^{\prime}$ and $30^{\circ} 56^{\prime} \mathrm{N}$ and $79^{\circ} 4^{\prime}$ and $79^{\circ} 15^{\prime} \mathrm{E}$, draining in northwestern direction, is an excellent source of psychrophiles. Gangotri glacier is around $30 \mathrm{~km}$ in length, $143 \mathrm{~km}^{2}$ in area and it is the largest valley type glacier in the western Himalaya [1]. The temperature is $2-5^{\circ} \mathrm{C}$ in summer and subzero in winter. Psychrophiles have attracted attention as source of enzymes with potential for low temperature catalysis. Indeed a variety of cold active enzymes have been found in psychrophiles [24]. One such example is cold active lipases, which are largely distributed in microorganisms existing at low temperatures nearly $5^{\circ} \mathrm{C}$. Lipases (triacylglycerol acylhydrolase, E. C. 3.1.1.3) are hydrolytic enzymes, which act on the carboxyl ester bonds present in acylglycerol to liberate fatty acids and glycerol. The knowledge of cold adapted lipolytic enzymes in industrial applications is increasing at a rapid and exciting rate. Cold active lipases are one of the important and widely used enzymes whose spectrum of applications has widened in many industries such as in detergent formulations, food industry, leather processing, environmental bioremediations, and fine chemical synthesis as well as in pharmaceutical industries [5]. However, their production cost limits their industrial use $[6,7]$. Therefore, it is of interest to increase the productivity of fermentation processes by optimization of culture conditions. Since the raw materials employed in the culture medium contribute to total production costs, the reduction in the substrate cost would be a suitable strategy to increase the productivity of the process [8]. Conventionally, submerged fermentation is employed for production of bacterial lipase. However, emerging trends emphasize that semi-solid and solid-state fermentation systems have real potential for the judicious management of bacteria in industry. 
Semisolid state fermentation (SmSSF) involves growth of microorganism on moist solid substrates in the absence of free flowing water. In SmSSF, the nature of the solid support material is an important parameter that influences the product yield and, consequently, there is a continuous search for newer and better substrates $[9,10]$. Lipase production by SmSSF is suitable since it offers many advantages over submerged fermentation $(\mathrm{SmF})$, which include high productivity, higher product concentration, simpler equipments and the use of low cost substrates as agro-industry waste products [11]. India is one of the world's leading oilseeds producing country. Oil cakes have high nutritional value, as they possess high protein content (ranging from 15 to $50 \%$ ). They are economically cheap, stable and dependable sources available in large quantities throughout year. The potential role of oil cake as a substrate for fermentation has been established [12]. Studies with oil cake extract showed significant results for the overproduction of lipases [13]. Moreover, the blending of different substrates shows still better performance, by providing more suitable environment for microbial growth. In the present study, the ability of Micrococcus roseus to produce extracellular cold active lipases under semi-solid state fermentation using oil cakes has been evaluated. This method may result in selecting an ideal substrate for economic production. Moreover, the maximum enzyme production by blending different substrate has been studied.

\section{Materials and Methods}

2.1. Bacterial Strain. Lipolytic bacterial strains were isolated from soil samples of Gangotri glacier, Western Himalayas on tributyrin agar plates [14] and observed for zone of clearance around the colonies. The organism which produced larger zone was isolated and identified as Micrococcus roseus by morphological and biochemical characteristics based on Bergey's Manual of Determinative Bacteriology [15]. The stock culture was maintained on Nutrient broth (Hi-Media) and glycerol $(50: 50 \% \mathrm{v} / \mathrm{v})$ at $-20^{\circ} \mathrm{C}$. Working cultures were prepared by two successive transfers of stock culture to nutrient broth for $24 \mathrm{~h}$ at $15 \pm 1^{\circ} \mathrm{C}$.

2.2. Inoculum Preparation. A loopful of cells from freshly grown culture of the potential lipolytic isolate was transferred to a $250 \mathrm{~mL}$ conical flask containing $100 \mathrm{~mL}$ nutrient broth. It served as a seed culture for further use as an inoculum after $48 \mathrm{~h}$ of incubation at $15 \pm 1^{\circ} \mathrm{C}$. Five milliliters of inoculum $\left(10^{8}\right.$ cells $\left./ \mathrm{mL}\right)$ was added to the sterilized medium for fermentation.

2.3. Semi-Solid State Fermentation. The substrates used for the production of cold active lipases were different oil cakes such as groundnut (GOC), coconut (COC), gingili (GngOC), mustard (MOC), and castor (CastOC) procured from the local market. Dry oil cake $(10 \mathrm{~g})$ was taken in $250 \mathrm{~mL}$ Erlenmeyer flask with $90 \mathrm{~mL}$ of double distilled water. The contents of the flask were mixed thoroughly and autoclaved at $121^{\circ} \mathrm{C}$ for $15 \mathrm{~min}$.
2.4. Extraction of Enzyme. After fermentation, phosphate buffer $(\mathrm{pH} 8)$ was added $(1: 1)$ to the fermented medium and the enzyme is extracted by centrifugation at $10,000 \mathrm{rpm}$ at $4^{\circ} \mathrm{C}$ for $10 \mathrm{~min}$. The clear supernatant obtained was used as crude enzyme and stored in sterilized vials for further use.

2.5. Lipase Assay. Lipase activity was assayed using $p$-nitro phenyl palmitate ( $p$ NPP) as a substrate as described by Winkler and Stuckmann [16]. Briefly, substrate solution containing phosphate buffer $(90 \mathrm{~mL})$ with Gum Arabic (100 mg), and sodium deoxycholate $(207 \mathrm{mg}$ ) along with $30 \mathrm{mg}$ of $p \mathrm{NPP}$ in $10 \mathrm{~mL}$ of isopropanol was preincubated with the crude enzyme at $15 \pm 1^{\circ} \mathrm{C}$. The release of $p$-nitrophenol $(p N P)$ was measured spectrophotometrically at $405 \mathrm{~nm}$. One unit of lipase activity was defined as the amount of enzyme releasing $1 \mu \mathrm{mol} p \mathrm{NP}$ under standard assay conditions.

2.6. Optimization of Production Parameters for SmSSF Using Oil Cakes. Optimization of process parameters and manipulation of media composition are one of the most important techniques used for the overproduction of lipase to meet industrial demands. Optimization was carried out through modification of several growth parameters. The effect of an individual parameter was standardized at a time before standardizing the next parameter. The various parameters optimized for obtaining maximal lipase yield were, incubation time $(24,48,72$ and $96 \mathrm{~h})$, temperature $(10,15,25$, 30 and $35^{\circ} \mathrm{C}$ ), and $\mathrm{pH}$ (ranging from 5.0-10.0). The effect of lipid materials as triglycerides $0.5 \% \mathrm{v} / \mathrm{v}$ such as castor oil, soybean oil, olive oil, and mustard oil was determined. Further the effect of supplementation of carbon sources (1\% $\mathrm{w} / \mathrm{v})$ such as glucose, sucrose, lactose, maltose, and nitrogen sources $(1 \% \mathrm{w} / \mathrm{v})$, that is, ammonium nitrate, potassium nitrate, peptone, beef extract, yeast extract, in the SmSSF system were also examined for production of cold active lipase. In the above process, after optimization of incubation time, oil cake showing highest lipase activity was selected as potential substrate for the SmSSF system, and further optimization of all other parameters was carried out with this substrate. For each step lipase activity was assayed to know the optimal yield.

2.7. Mixed Substrate Fermentation. In view of above experiments, studies were made to evaluate the mixed substrate fermentation by mixing the oil cake showing maximum lipase yield with other oil cakes in ratio $1: 1$. Best mixed preparation was selected; further, the above optimized ingredients were tested for mixed substrate enrichment. The enriched media were designated as media A to E.

Media A: Combination of mixed substrate showing maximum production of cold active lipase.

Media B: Media A + triglyceride $(0.5 \% \mathrm{v} / \mathrm{v})$.

Media C: Media A + Carbon source (1\%w/v).

Media D: Media A + Nitrogen source $(2 \% \mathrm{w} / \mathrm{v})$.

Media E: Media A + Carbon + Nitrogen source. 


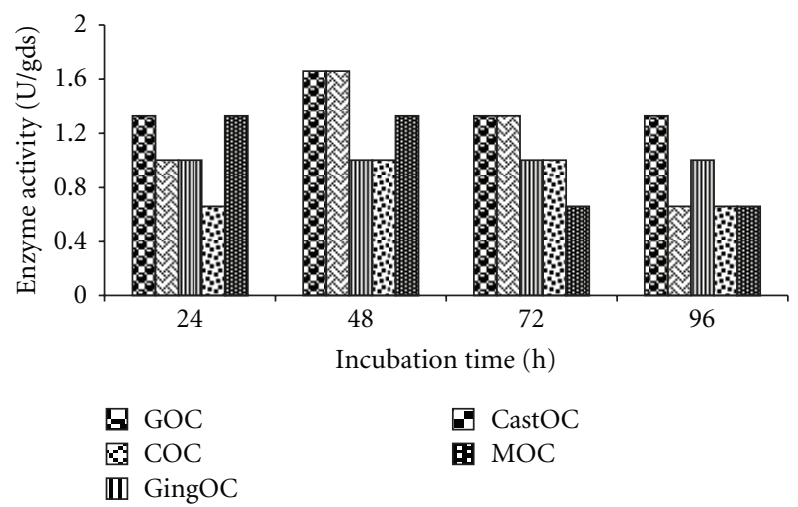

Figure 1: Cold active lipase production at different time intervals using different oil cakes as substrate from Micrococcus roseus under SmSSF.

2.8. Characterization of Lipase. Activity of the crude lipase at different $\mathrm{pH}$ values was measured adjusting $\mathrm{pH}$ of the reaction mixture using $(0.1 \mathrm{M})$ of following buffers: citrate buffer (pH 5.0-6.5), Tris-chloride buffer ( $\mathrm{pH}$ 7.0-9.0), and Glycine$\mathrm{NaOH}$ buffer ( $\mathrm{pH} 10)$. The enzyme activity was assayed by method described before. To study the stability at different $\mathrm{pH}$, cold active lipase was dissolved in above-mentioned buffers. These enzyme solutions were preincubated at $15^{\circ} \mathrm{C}$ for $1 \mathrm{~h}$ and relative activity was measured. To study the effect of temperature on activity of lipase, reaction mixture was incubated at different temperatures ranging from $5-50^{\circ} \mathrm{C}$ for $15 \mathrm{~min}$ and activity was determined. To study the lipase stability at different temperature, lipase was dissolved in $50 \mathrm{mM}$ phosphate buffer ( $\mathrm{pH} \mathrm{8.0)}$, pre-incubated at different temperatures ranging from 0 to $50^{\circ} \mathrm{C}$ for $1 \mathrm{~h}$, rapidly relative activity was measured by the standard assay procedure.

\section{Results and Discussion}

Twelve lipolytic bacterial colonies were isolated on tributyrin agar medium from the five different soil samples of Gangotri glacier (data not shown). Microbiological analysis of soil samples showed that the soil of glacier region contains high bacterial count growing at $15 \pm 1^{\circ} \mathrm{C}$. Among these 12 lipolytic strains, isolate CAL-7 showing clear zone of maximum diameter on tributyrin agar medium at $15 \pm 1^{\circ} \mathrm{C}$ was selected as potential strain for cold active lipase production. The isolate CAL-7 was later identified as M. roseus on the basis of biochemical tests performed (Table 1).

Selection of a suitable substrate for the production of enzyme is a primary-key factor and an extremely significant step. In the present study, the production of cold active bacterial lipase by $M$. roseus was tested in semi-solid state fermentation using various oil cakes as substrate. The effect of incubation time showed that there is large difference in the production of lipase with different oil cakes as substrates (Figure 1). The maximum yield of lipase (1.66 U/gds) was noted in groundnut oil cake among the various substrate tested. The suitability of GOC may be due to the high content of crude protein. A low level of lipase activity was
TABLE 1: Morphological and biochemical characteristics shown by the potential isolate CAL-7.

\begin{tabular}{|c|c|}
\hline Tests & Results \\
\hline \multicolumn{2}{|l|}{ Colony morphology } \\
\hline Configuration & Round/circular \\
\hline Margin & Entire \\
\hline Elevation & Convex \\
\hline Surface & Smooth/glistening \\
\hline Density & Opaque \\
\hline Pigments & Rosy red \\
\hline Grams reaction & Positive \\
\hline Shape & Cocci \\
\hline Size & Small \\
\hline Arrangement & Single or in pairs \\
\hline Spore & Absent \\
\hline \multicolumn{2}{|l|}{ Biochemical tests } \\
\hline Catalase & + \\
\hline Oxidase & - \\
\hline Indole & - \\
\hline Methyl red & + \\
\hline Voges Prausker & - \\
\hline Citrate utilization & - \\
\hline Urease & - \\
\hline Nitrate reduction & + \\
\hline Gelatin hydrolysis & - \\
\hline Casein hydrolysis & - \\
\hline Starch hydrolysis & - \\
\hline Cween 80 hydrolysis & - \\
\hline Hydrogen sulphide production & - \\
\hline Motility test & $-/ \mathrm{w}$ \\
\hline \multicolumn{2}{|l|}{ Sugar fermentation } \\
\hline Glucose & A \\
\hline Xylose & A \\
\hline Sucrose & A \\
\hline Fructose & A \\
\hline Maltose & A \\
\hline Galactose & A \\
\hline Mannitol & $\mathrm{A}$ \\
\hline
\end{tabular}

+: Positive, -: Negative, A: Acid, w: weak.

obtained in the earlier stages of incubation which steadily reached maximum level by $48 \mathrm{~h}$ of incubation. Beyond $48 \mathrm{~h}$, a steep loss in the production was observed which could be due to depletion of nutrients. Several workers also reported the effect of incubation time on cold active lipase production. Serratia marcesecens produced lipase after 6 days of incubation [17] and Psychrobacter sp. Ant300 [18] and Pseudoalteromonas sp. wp27 [19] synthesized cold active lipase after 14 days of incubation. However, in the present study, $M$. roseus was able to produce cold active lipase within $48 \mathrm{~h}$ of incubation.

When the lipase yield in semi-solid state fermentation system was compared with that of submerged fermentation system the lipase activity was reported to show 1.6-fold 


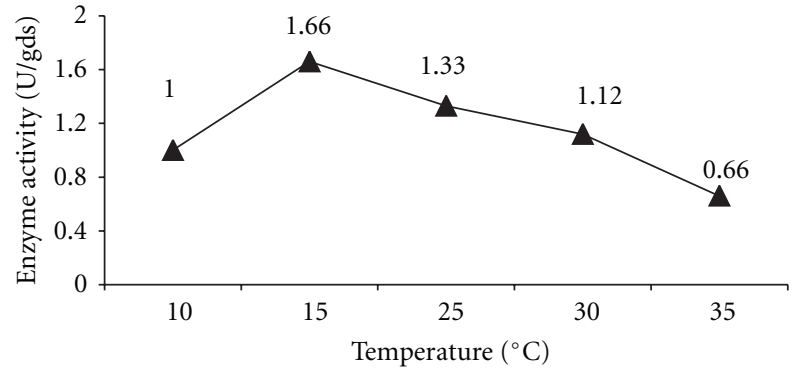

Figure 2: Cold active lipase production at different temperatures using groundnut oil cake as substrate.

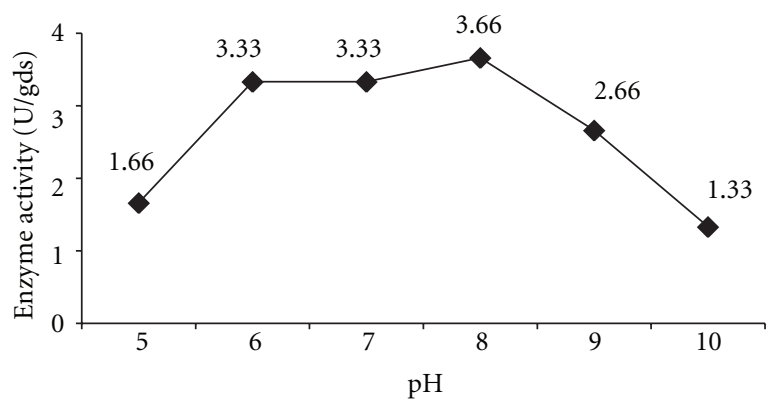

Figure 3: Cold active lipase production at different $\mathrm{pH}$ using groundnut oil cake as substrate.

TABLE 2: Effect of triglycerides, carbon source, and nitrogen sources in cold active lipase production.

\begin{tabular}{llc}
\hline \multicolumn{2}{c}{ Additional sources } & Lipase activity (U/gds) \\
\hline & Control & 3.66 \\
& Castor oil & 3.00 \\
Triglycerides $(0.5 \% \mathrm{v} / \mathrm{v})$ & Soybean oil & 1.33 \\
& Olive oil & 1.33 \\
& Mustard oil & 0.66 \\
\hline & Glucose & 4.66 \\
Carbon source $(1 \% \mathrm{w} / \mathrm{v}))$ & Sucrose & 3.33 \\
& Lactose & 2.00 \\
& Maltose & 2.00 \\
\hline & $\mathrm{NH}_{4} \mathrm{NO}_{3}$ & 5.33 \\
& $\mathrm{KNO}_{3}$ & 2.66 \\
Nitrogen source $(1 \% \mathrm{w} / \mathrm{v})$ & Peptone & 5.33 \\
& Beef extract & 3.33 \\
& Yeast extract & 3.33 \\
\hline
\end{tabular}

increase in SmSSF system (data not shown). Similar result was reported by [20], which pointed out the superiority of solid state fermentation over traditional suspension culture. Therefore the SmSSF showing higher lipase yield was found to be an appropriate system for the overproduction of cold active lipase for industrial benefits.

Micrococcus roseus was found to be a psychrophilic microorganism having an optimum temperature for growth at $15 \pm 1^{\circ} \mathrm{C}$ with maximum lipase yield. On increasing the temperature to $35^{\circ} \mathrm{C}$, cold active lipase production was tremendously decreased (Figure 2). The absence of lipase activity in the culture supernatant above $35^{\circ} \mathrm{C}$ is likely due to the thermolability of enzyme. The cold adapted microorganisms tend to have good growth at low temperature and production of cold active lipase is considered to be temperature dependent and thermolabile [21].

In the present case the isolate was found to be growing and producing the lipases over wide range of $\mathrm{pH}$ values (Figure 3). The maximum production of lipase was obtained at $\mathrm{pH} 8.0(3.66 \mathrm{U} / \mathrm{gds})$. An alkaline stable lipase is used for the enzymatic hydrolysis of tributyrin [22]. The cold active lipase produced owing to its alkaline nature seems to be of considerable importance in industrial processes such as leather processing, sewage treatment, and detergent formulations.

The supplementation of different triglycerides, that is, castor oil, soybean oil, olive oil, and mustard oil at $0.5 \%$ concentration was not desirable as it suppressed the production of lipase in SmSSF medium (Table 2). This might be because the substrate itself would have provided the necessary lipid source. It might be due to the fact that higher oil content resulted in the formation of a biphasic system which prevented not only the accessibility of water to the microorganism but also prevented the oxygen transfer and nutrient assimilation by the microorganism from the substrate. Butter oil, corn oil, or olive oil inhibited production of lipase by Penicillium roqueforti [23]. Further addition of inducers can be avoided which offers economic benefits for industrial scale production of cold active lipases. The impact of additional carbon sources at $1 \%(\mathrm{w} / \mathrm{v})$ was studied (Table 2$)$. It was found that, glucose when used as an additional carbon source induced maximum production of cold active lipase (4.66 U/gds). However, sucrose, lactose and maltose were found to be notably repressing the lipase production. Glucose is an easily available cheap carbon source which is easily utilized by the bacteria, hence it can be efficiently used for improved production of cold active lipases.

The effect of supplementation of inorganic and organic nitrogen sources in SmSSF system is shown in Table 2. Ammonium nitrate and peptone $(1 \% \mathrm{w} / \mathrm{v})$ when used as additional nitrogen sources increased the production of cold active lipase from $M$. roseus upto $5.33 \mathrm{U} / \mathrm{gds}$ in each case. However, supplementation of potassium nitrate, beef extract, and yeast extract do not have any significant role in increasing the production of cold active lipase. Similar to above findings, few reports are available on peptone as the best carbon source [24] and increase in production of lipase when ammonium nitrate was supplied as inorganic nitrogen source to the organism [25].

Among different mixed substrate preparations, groundnut oil cake along with mustard oil cake was found to show maximum production of cold active lipase $4.33 \mathrm{U} / \mathrm{gds}$ at $\mathrm{pH} 8.0$ after $48 \mathrm{~h}$ of incubation at $15 \pm 1^{\circ} \mathrm{C}$. While mixed preparations of GOC along with other oil cakes did not show any significant result for the production of cold active lipases (Figure 4). Since lipase yield was increased up to 1.2-fold after using the mixed preparation of GOC along with MOC, hence this preparation was selected for further production of cold active lipase. A higher lipase 


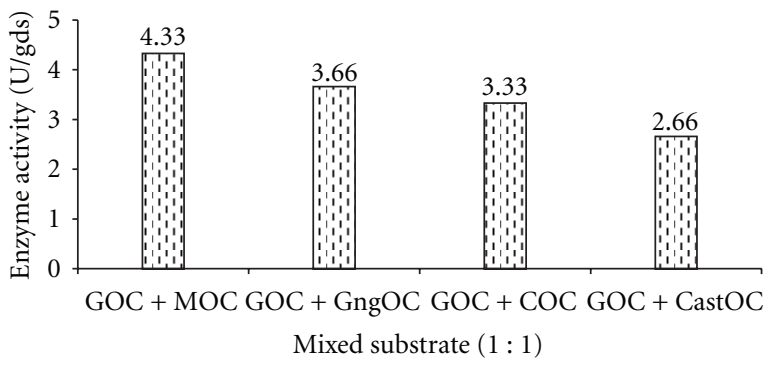

FIgUre 4: Production of cold active lipases through SmSSF using mixed substrate preparation.

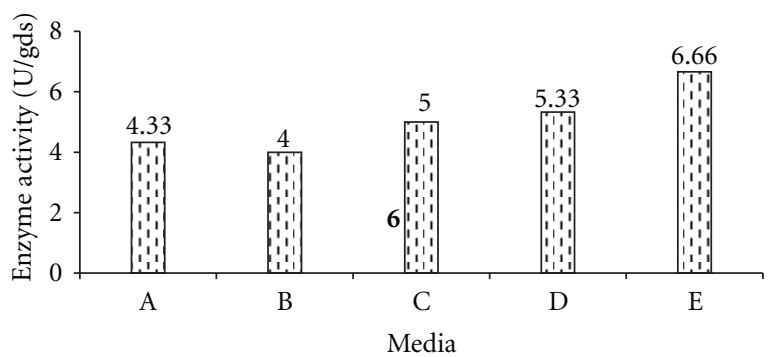

FIGURe 5: Production of cold active lipases through different media preparation under optimized conditions.

yield was obtained in mixed substrate preparation from Candida rugosa [26]. The supplementation of GOC along with MOC $(1: 1)$, that is, media A with different nutrient sources individually such as triglycerides, glucose as carbon source, ammonium nitrate as nitrogen source as well as with the combination of glucose and ammonium nitrate, which were designated as media B, C, D, and E were tested and results obtained are given in Figure 5. The increased production of cold active lipase was obtained with glucose $5.00 \mathrm{U} / \mathrm{gds}$, ammonium nitrate $5.33 \mathrm{U} / \mathrm{gds}$, as well as with the combination of glucose and ammonium nitrate $6.66 \mathrm{U} / \mathrm{gds}$. Production of cold active lipases from $M$. roseus was reported to show $150 \%$ increased production after optimization of mixed preparation. Similarly, a higher lipase production by Aspergillus niger on optimization of mixed substrate in ratio of $1: 1$ [27] was obtained in fungal fermentation process.

The optimum reaction temperature for lipase was $15^{\circ} \mathrm{C}$ when $p$-nitro phenyl palmitate ( $p$-NPP) was used as substrate. Reaction mixture when incubated at $40^{\circ} \mathrm{C}$ showed less activity. Micrococcus roseus lipase was stable up to $30^{\circ} \mathrm{C}$ but rapidly inactivated at higher temperature above $40^{\circ} \mathrm{C}$ when incubated for $1 \mathrm{~h}$ (Figure 6 ). The activity of the cold enzyme presents an apparent optimal activity around $35^{\circ} \mathrm{C}$ and retains about $20 \%$ of its activity at $0^{\circ} \mathrm{C}$, whereas the activity of the mesophilic lipases is close to zero at temperatures below $20^{\circ} \mathrm{C}$ and increases at temperatures above $60^{\circ} \mathrm{C}$ [28]. The increased catalytic activity at low temperatures and decreased thermostability of psychrophilic enzymes suggest that there is a relationship between stability and activity to maintain the activity at low temperature. This marked liability of $M$. roseus lipase together with its high catalytic efficiency near $15^{\circ} \mathrm{C}$ clearly denotes that it

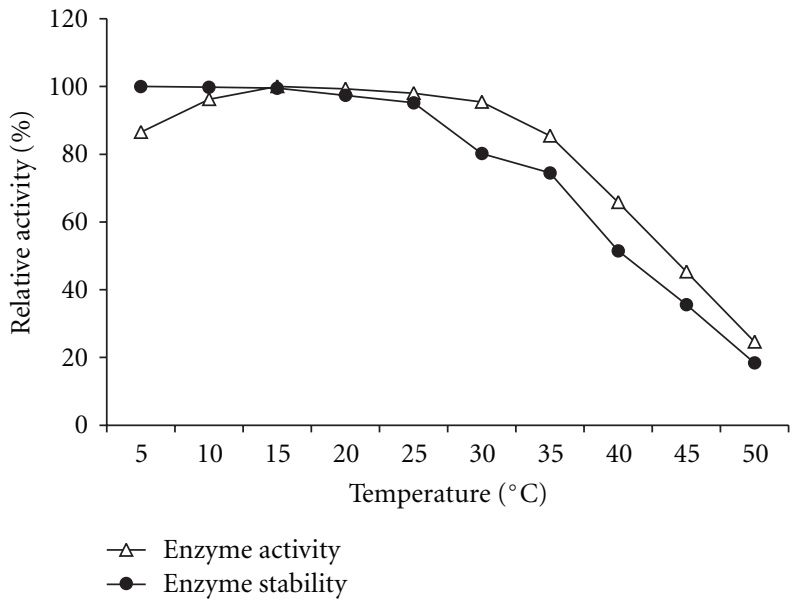

FIgURE 6: Enzyme activity $(\Delta)$ and stability $(\bullet)$ of cold active lipases at various temperatures. The relative activity (\%) was calculated relative to the case of reaction at which maximum activity was taken as $100 \%$.

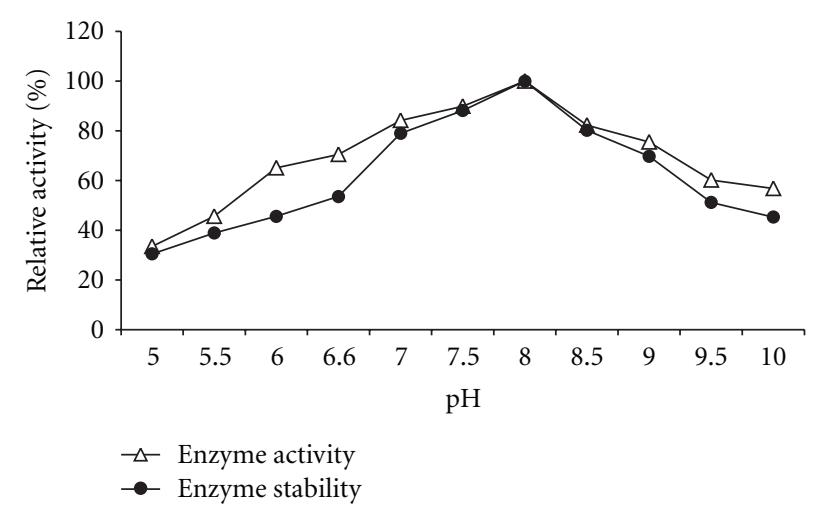

Figure 7: Enzyme activity $(\Delta)$ and stability $(\bullet)$ of cold active lipases from M. roseus at various $\mathrm{pH}$ at $15^{\circ} \mathrm{C}$. The relative activity (\%) was calculated relative to the case of reaction at which maximum activity was taken as $100 \%$.

is cold active enzyme. Maximum activity and stability of cold active lipase was obtained at $\mathrm{pH}$ 8.0. The enzyme was stable under a $\mathrm{pH}$ range of 7.0-9.0 with slightly more in alkaline conditions (Figure 7). Lipases showing high stability and activity over a wide range of $\mathrm{pH}$ and activity under nonconventional conditions are of great interest. The major commercial application for alkaline stable lipases is the use in laundry and household detergents. M. roseus lipase was stable $(>60 \%)$ over a $\mathrm{pH}$ range of $7.0-9.0$; therefore, it has great potential for application in detergent industry as an additive used for cold washing.

\section{Conclusion}

Agricultural waste utilization for industrial development is one of the developing areas in modern industrial biotechnology. As shown in present research, the cold active bacterial lipases could be economically produced by $M$. roseus under semi-solid state fermentation using cheaply 
available groundnut oil cake as potent substrate. However, blending of Croundnut oil cake along with mustard oil cake $(1: 1)$ under optimized condition showed better yield of cold active lipase. Groundnut oil cake and mustard oil cake along with glucose and ammonium nitrate was found to be a promising substrate for industrial production of cold active lipase in SmSSF by providing all the nutrients for the anchorage of cells. Further, it is reported that production of cold active lipase through SmSSF might not only reduce the cost of production but also results in manyfold increase in the lipase yield when compared with submerged fermentation. The study thus conducted has tried to expand the horizon of our knowledge on the cold active bacterial lipases which represents an extremely versatile group of bacterial extracellular enzymes that are capable of performing a variety of important reactions, thereby presenting a fascinating field for future research.

\section{References}

[1] J. Singh and R. R. Yadav, "Tree-ring indications of recent glacier fluctuations in Gangotri, western Himalaya, India," Current Science, vol. 79, no. 11, pp. 1598-1601, 2000.

[2] G. Feller, E. Narinx, J. L. Arpigny et al., "Enzymes from psychrophilic organisms," FEMS Microbiology Reviews, vol. 18, no. 2-3, pp. 189-202, 1996.

[3] C. J. Marshall, "Cold-adapted enzymes," Trends in Biotechnology, vol. 15, no. 9, pp. 359-364, 1997.

[4] C. Gerday, M. Aittaleb, M. Bentahir et al., "Cold-adapted enzymes: from fundamentals to biotechnology," Trends in Biotechnology, vol. 18, no. 3, pp. 103-107, 2000.

[5] B. Joseph, P. W. Ramteke, G. Thomas, and N. Shrivastava, "Review Cold-active Lipases: a versatile tool for industrial applications," Biotechnology and Molecular Biology Reviews, vol. 2, pp. 39-48, 2007.

[6] A. Kademi, L. Danielle, and H. Ajain, "Lipases," in Enzyme Technology, pp. 297-318, Asiatech, New Delhi, India, 2005.

[7] B. Joseph, P. W. Ramteke, and P. A. Kumar, "Studies on the enhanced production of extracellular lipase by Staphylococcus epidermidis," Journal of General and Applied Microbiology, vol. 52, no. 6, pp. 315-320, 2006.

[8] A. Domínguez, M. Costas, M. A. Longo, and A. Sanromán, “A novel application of solid state culture: production of lipases by Yarrowia lipolytica," Biotechnology Letters, vol. 25, no. 15, pp. 1225-1229, 2003.

[9] K. E. Aidoo, R. Hendry, and B. J. B. Wood, "Solid substrate fermentations," Advances in Applied Microbiology, vol. 28, no. C, pp. 201-237, 1982.

[10] A. Pandey, "Recent process developments in solid-state fermentation," Process Biochemistry, vol. 27, no. 2, pp. 109-117, 1992.

[11] N. Perez-Guerra, A. Torrado-Agrasar, C. Lopez-Macias, and L. Pastrana, "Main characteristics and applications of solid substrate fermentation," Electronic Journal of Environmental, Agricultural and Food Chemistry, vol. 2, pp. 1-6, 2003.

[12] S. Benjamin and A. Pandey, "Coconut cake-a potent substrate for the production of lipase by Candida rugosa in solidstate fermentation," Acta Biotechnologica, vol. 17, no. 3, pp. 241-251, 1997.

[13] S. Benjamin and A. Pandey, "Optimization of liquid media for lipase production by Candida rugosa," Bioresource Technology, vol. 55 , no. 2 , pp. $167-170,1996$.
[14] A. M. Farrell, T. J. Foster, and K. T. Holland, "Molecular analysis and expression of the lipase of Staphylococcus epidermidis," Journal of General Microbiology, vol. 139, no. 2, pp. 267-277, 1993.

[15] J. G. Holt, N. R. Krieg, P. H. A. Sneath, J. T. Staley, and S. T. Williams, Bergey's Manual of Determinative Bacteriology, Williams \& Wilkins, Baltimore, Md, USA, 9th edition, 1994.

[16] U. K. Winkler and M. Stuckmann, "Glycogen, hyaluronate, and some other polysaccharides greatly enhance the formation of exolipase by Serratia marcescens," Journal of Bacteriology, vol. 138, no. 3, pp. 663-670, 1979.

[17] H. K. Lee, M. J. Ahn, S. H. Kwak, W. H. Song, and B. C. Jeong, "Purification and characterization of cold active lipase from psychrotrophic Aeromonas sp. LPB 4," Journal of Microbiology, vol. 41, no. 1, pp. 22-27, 2003.

[18] L. Kulakova, A. Galkin, T. Nakayama, T. Nishino, and N. Esaki, "Cold-active esterase from Psychrobacter sp. Ant300: gene cloning, characterization, and the effects of Gly $\rightarrow$ Pro substitution near the active site on its catalytic activity and stability," Biochimica et Biophysica Acta, vol. 1696, no. 1, pp. 59-65, 2004.

[19] X. Zeng, X. Xiao, P. Wang, and F. Wang, "Screening and characterization of psychrotrophic, lipolytic bacteria from deepsea sediments," Journal of Microbiology and Biotechnology, vol. 14, no. 5, pp. 952-958, 2004.

[20] C. W. Hesseltine, "Solid state fermentation-an overview," International Biodeterioration, vol. 23, no. 2, pp. 79-89, 1987.

[21] N. Rashid, Y. Shimada, S. Ezaki, H. Atomi, and T. Imanaka, "Low-temperature lipase from psychrotrophic Pseudomonas sp. strain KB700A," Applied and Environmental Microbiology, vol. 67, no. 9, pp. 4064-4069, 2001.

[22] D. W. Choo, T. Kurihara, T. Suzuki, K. Soda, and N. Esaki, "A cold-adapted lipase of an Alaskan psychrotroph, Pseudomonas sp. strain B11-1: gene cloning and enzyme purification and characterization," Applied and Environmental Microbiology, vol. 64, no. 2, pp. 486-491, 1998.

[23] R. R. Eitenmiller, J. R. Vakil, and K. M. Shahani, "Enzymes of food industry," Food Science, vol. 35, pp. 130-133, 1970.

[24] R. K. Saxena, A. Sheoran, B. Giri, and W. S. Davidson, "Purification strategies for microbial lipases," Journal of Microbiological Methods, vol. 52, no. 1, pp. 1-18, 2003.

[25] S. C. B. Gopinath, A. Hilda, T. Lakshmi Priya, G. Annadurai, and P. Anbu, "Purification of lipase from Geotrichum candidum: conditions optimized for enzyme production using Box-Behnken design," World Journal of Microbiology and Biotechnology, vol. 19, no. 7, pp. 681-689, 2003.

[26] S. Benjamin and A. Pandey, "Mixed-solid substrate fermentation. A novel process for enhanced lipase production by Candida rugosa," Acta Biotechnologica, vol. 18, no. 4, pp. 315324, 1998.

[27] H. S. Pau and I. C. Omar, "Selection and optimization of lipase production from Aspergillus flavus USM A10 via solid state fermentation on rice husks and wood dusts as substrates," Pakistan Journal of Biological Sciences, vol. 7, pp. 1249-1256, 2004.

[28] C. Gerday, M. Aittaleb, J. L. Arpigny et al., "Psychrophilic enzymes: a thermodynamic challenge," Biochimica et Biophysica Acta, vol. 1342, no. 2, pp. 119-131, 1997. 

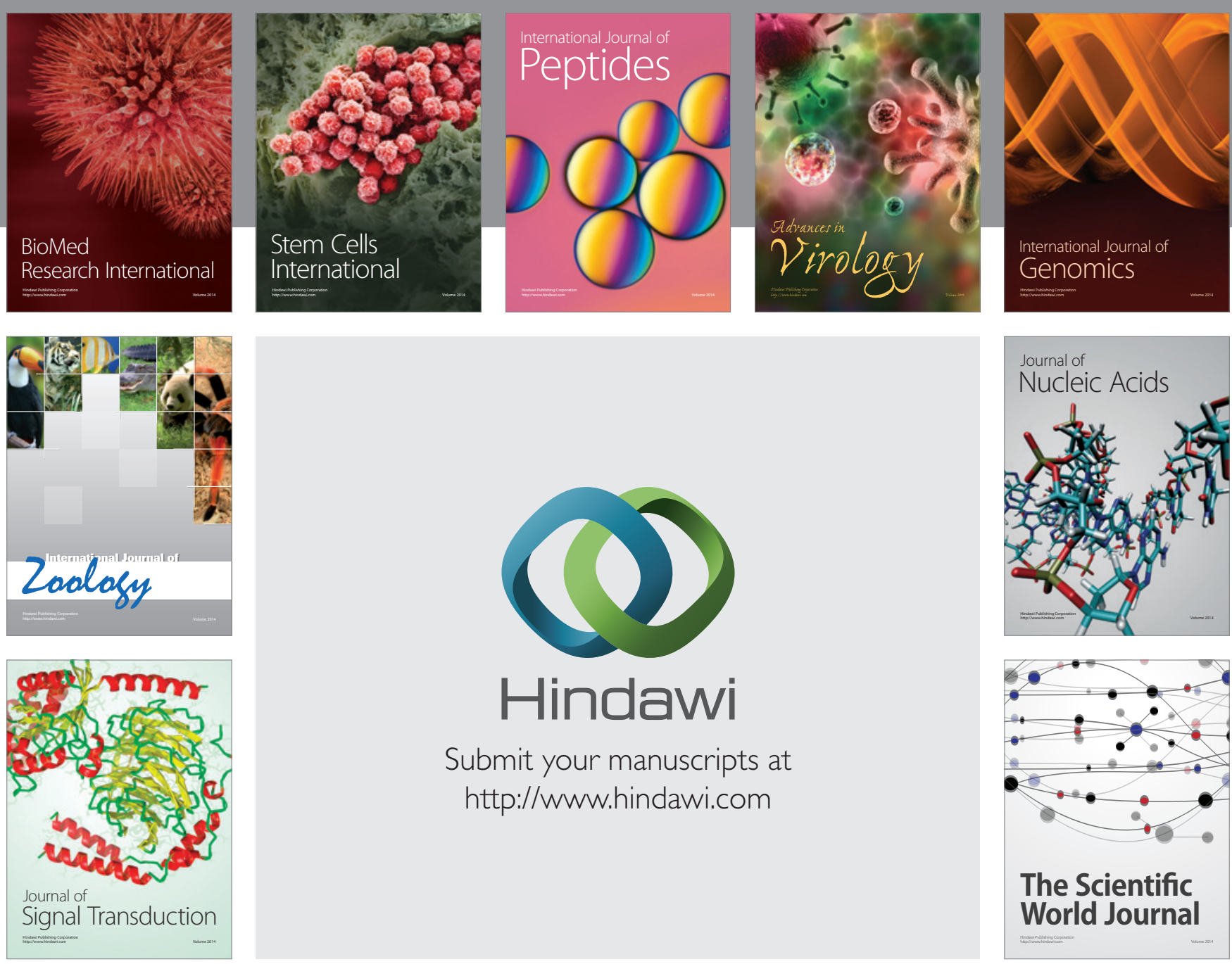

Submit your manuscripts at

http://www.hindawi.com
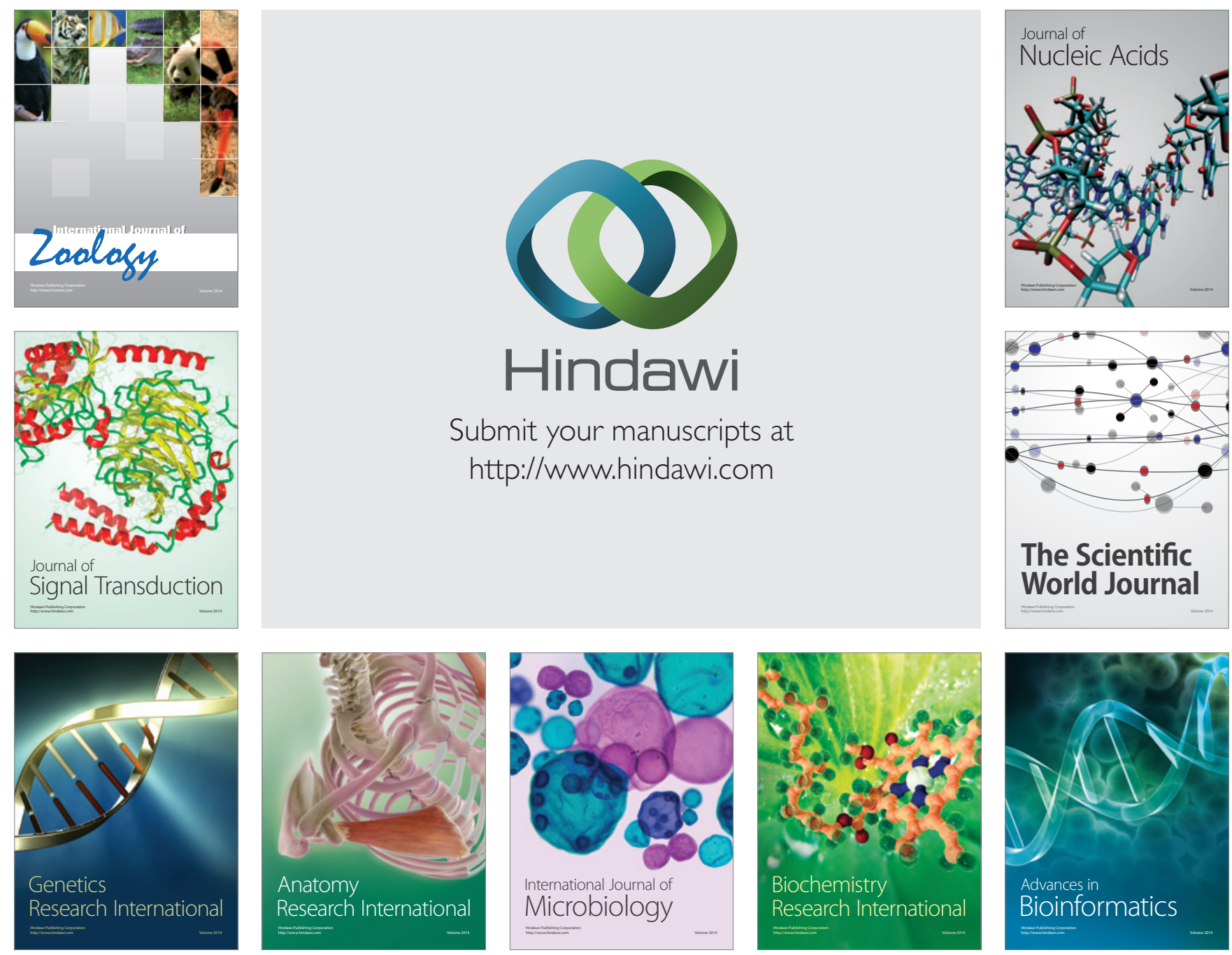

The Scientific World Journal
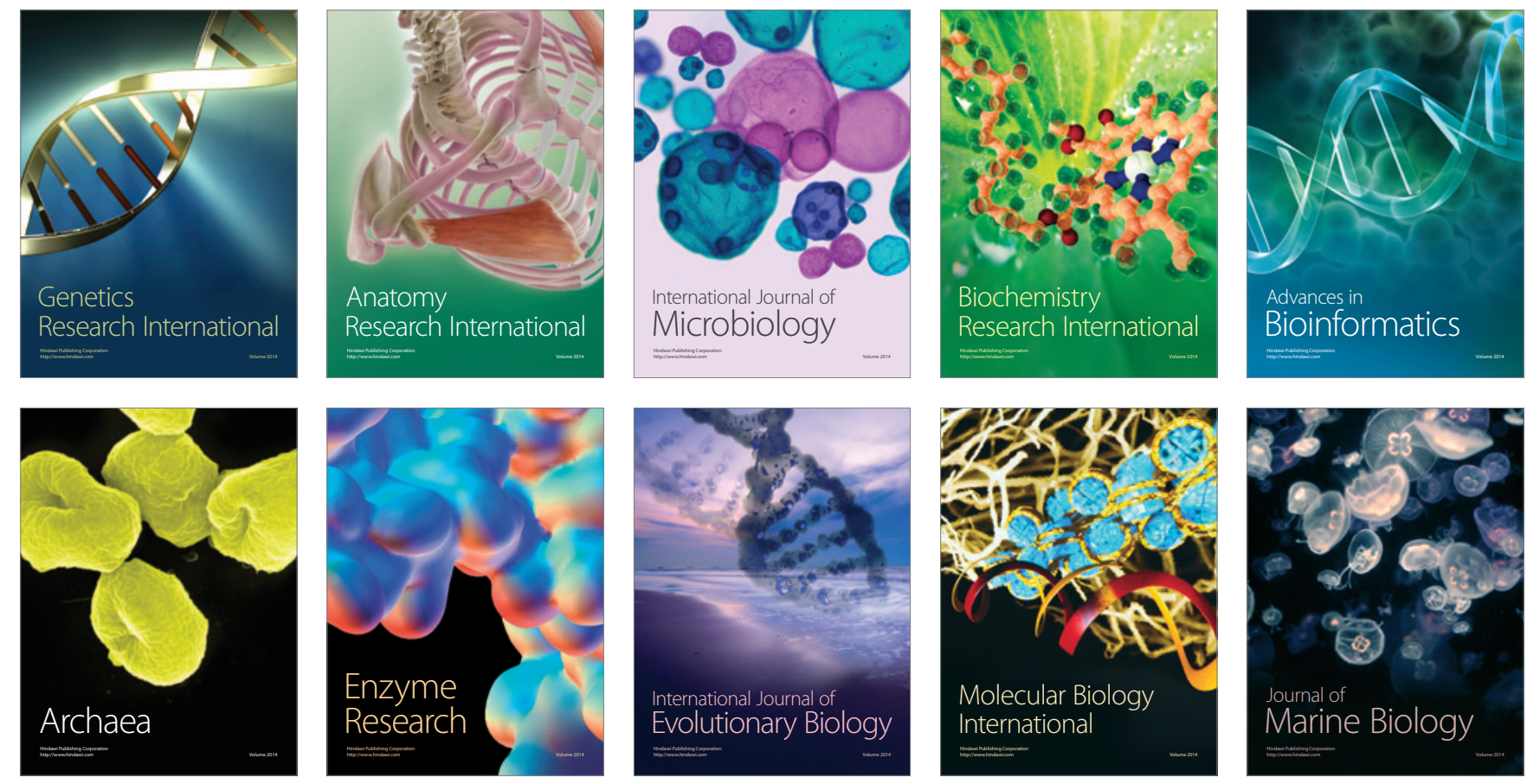